\title{
Global Governance of Global Monetary Relations: Rationale and Feasibility
}

\section{Citation}

Frieden, Jeffry A. 2009. Global governance of global monetary relations: Rationale and feasibility. Economics 3:2009-6.

\section{Published Version}

http://www.economics-ejournal.org/economics/journalarticles/2009-6;doi:10.5018/economicsejournal.ja.2009-6

\section{Permanent link}

http://nrs.harvard.edu/urn-3:HUL.InstRepos:4214913

\section{Terms of Use}

This article was downloaded from Harvard University's DASH repository, and is made available under the terms and conditions applicable to Open Access Policy Articles, as set forth at http:// nrs.harvard.edu/urn-3:HUL.InstRepos:dash.current.terms-of-use\#OAP

\section{Share Your Story}

The Harvard community has made this article openly available.

Please share how this access benefits you. Submit a story.

Accessibility 


\title{
Global Governance of Global Monetary Relations: Rationale and Feasibility
}

\author{
Jeffry A. Frieden \\ Department of Government, Harvard University
}

\begin{abstract}
Is there a valid argument for international cooperation, and some form of international governance structure, in the international monetary realm? On the purely economic front, the argument is not strong. Yet a broader political economy approach concludes that national currency policy can in fact impose non-pecuniary externalities on partner nations. This is especially the case with major policy-driven misalignments, which cannot easily be countered by other governments. For example, one country's substantially depreciated currency can provoke powerful protectionist pressures in its trading partners, so that exchange rate policy spills over into trade policy in potentially damaging ways. Inasmuch as one government's policies create these sorts of costs for other countries, and for the world economy as a whole, there is a case for global governance. This might include some institutionalized mechanism to monitor and publicize substantial currency misalignments. While there appears to be little global political attention to such a mechanism now, there have been initiatives along these lines at the regional level, and the current crisis may have stimulated more general stirrings of interest.
\end{abstract}

Special issue "Global Governance-Challenges and Proposals for Reform”

Published as Policy Paper

JEL: F42, F55, H87

Keywords: International policy coordination and transmission; international institutional arrangements; international fiscal issues; international public goods.

\section{Correspondence}

Jeffry A. Frieden, Department of Government, Harvard University, 1737 Cambridge Street, Office 211, Cambridge , MA 02138, USA; e-mail: jfrieden@harvard.edu

Presented at a Symposium on "Global Governance - Proposals for Reform" on the occasion of the 70 th birthday of Professor Horst Siebert, Kiel, Germany, June 18, 2008. The author thanks Barry Eichengreen, Michael Klein, Niklas Potrafke, Symposium participants, and an anonymous reviewer for useful comments and suggestions. 


\section{Introduction}

Exchange rates have been the focus of a great deal of international attention over the past two decades. Spectacular currency crises in emerging markets have thrown whole regions into economic and political turmoil. Major countries have accused each other of purposely manipulating their currencies, leading to acrimonious disputes that implicate broader economic ties. Questions have been raised about the future role of the dollar and the euro as international currencies. What has been called "the international monetary non-system" (Corden 1983) is a prominent feature of the contemporary international economy

In what follows, I develop two ideas: that the lack of international monetary cooperation among major powers is a source of uncertainty and instability in the world economy, and that the world would be better off with a more encompassing governance structure to manage international monetary relations. I start with a discussion of the extent to which national exchange rate policies can impose negative externalities on other countries. This provides a justification for cooperative action to internalize - and reduce - such externalities, and for an institutionalized mechanism to encourage such cooperation. I then assess both the feasibility of such institutionalized cooperation, and some specifics of how it might work.

In a sense, this essay is an attempt to convince Horst Siebert that his long-standing interest in institutionalized international cooperation should be extended to the monetary realm. Professor Siebert is an eloquent supporter of "an international order... which prevents countries from falling into the trap of non-cooperative behavior" and of specific "mechanisms...that enable countries to get out of a situation of non-cooperative behavior" (Siebert 1999: 261). The justification for an institutionalization of cooperation comes, as is standard in the institutionalist literature, from the expectation that "institutional arrangements relating to the economic sphere... can be explained as serving to reduce transaction costs" (Siebert 2008: 4). Yet in the international monetary realm, Professor Siebert has steadfastly resisted any institutionalization of global cooperative mechanisms, or even any attention to systematic inter-state cooperation, on the grounds that "a solution can only consist in each individual country's keeping its own house in order and maintaining a stable domestic price level” (Siebert 1999: 146). I suggest that Professor Siebert's general principles apply in the international monetary realm as well: the existence of significant externalities justifies international cooperation, and the institutionalization of this cooperation can reduce transactions costs.

\section{The Problem: Exchange Rate Externalities}

Any argument for explicit collaboration among national governments rests on the presumption that purely national policymaking can produce collectively sub-optimal results. If national governments acting in their own self-interest adopt policies that are best for them and for others, then there is no scope for cooperation to improve welfare. 
And in exchange rate policy Horst Siebert's position, quoted above, is widely shared: the best outcomes will be obtained simply if individual governments adopt responsible macroeconomic policies, in their own self-interest. While at some level this is true, almost by definition — who could oppose responsible policies?-it is incomplete, and may lead to incorrect conclusions. In particular, the view neglects the implications of a theoretically grounded analysis of the political economy of macroeconomic policy.

An insistence that all that is necessary for optimal global policy outcomes is sensible national policy misses two important points, both relevant to international cooperation. First, whatever theory may say about aggregate welfare, governments typically face political pressures to satisfy particular groups in the population with policies that deviate from whatever the textbook welfare-maximizing ideal may be. These politically driven policies can have a negative impact on other countries; and cooperation among nations can help mitigate the effects of such particularistic policies. Second, even government policies that are optimal from a national standpoint (whether in purely economic or political-economy terms) may impose externalities on other countries, whether due to purposive strategic behavior such as free riding, or due to the fact that the external effects are not internalized.

This logic is widely accepted in many arenas, such as trade policy. ${ }^{1}$ Each country is, under most circumstances, best served by unilateral liberalization. ${ }^{2}$ Yet governments face powerful political incentives to erect or maintain protective barriers, despite the fact that this imposes efficiency costs on the national economy, and on the nation's trading partners. In this context, scholars have argued that a wide variety of international trade institutions can help governments cooperate to improve the welfare of all concerned. For example, the WTO institutionalizes reciprocity, thereby empowering domestic interests (especially exporters) who can oppose protectionist pressures; and its dispute settlement mechanism helps resolve complaints about national policies while reducing the risk of unilateral retaliation. ${ }^{3}$ There seems little doubt that the institutions of international trade perform the transactions cost-reducing role Siebert and others expect from an international governance structure, and do so in ways that increase the likelihood of a cooperative trade policy outcome and a joint increase in welfare.

In other words, there are at least two objections to the view that international cooperation is unwarranted because all that is necessary is that governments adopt nationally appropriate policies. First, we can reliably anticipate that government policy will often be driven by motives other than aggregate social welfare - such as getting

\footnotetext{
1 Indeed, Professor Siebert invokes this as an argument for international cooperation in trade policy and the WTO, despite the fact that - just as with macroeconomic policy - from a normative standpoint and in most instances each individual country would be best served by free trade (Siebert 1999, chapter 14).

2 The exception is in the case of a country that can use its market power to improve its terms of trade by an optimal tariff. While there may be evidence for the relevance of optimal tariff considerations for some aspects of trade policy, it seems clear that the structure and level of protection in most nations responds to political economy pressures as well.

3 See, for example, Busch and Reinhardt (2003), Davis (2004), Hoekman and Mavroidis (2000), and Mansfield et al. (2002).
} 
reelected, satisfying powerful domestic interest groups, or achieving non-economic goals. In this context, the uncoordinated pursuit of what is "nationally appropriate" in a political-economy sense may lead to outcomes that could be improved upon by interstate cooperation. Second, there are many instances in which national governments may not fully internalize the negative (and positive) externalities created by their own policies. These two factors are indeed the justification for virtually all international organizations. They can be combined in the following argument: the uncoordinated pursuit of national policies, determined in political-economy equilibrium, can create negative externalities for other nations, and thus can lead to a collectively inferior outcome.

In applying this reasoning to international monetary relations, the first step is to assess the extent to which this actually might pertain to national exchange rate policies. After all, if a government manipulates its currency, pulling it away from a defensible or realistic exchange rate, the principal effects will be felt at home. And it might be argued that to the extent that the movements of one country's currency imposes costs on another country, the latter can simply reverse the charges by counteracting the currency movement. Nonetheless, in currency affairs, as elsewhere, there are varieties of external effects that go beyond the impact on the national economy and national economic actors, and for which a unilateral response is either not possible or not desirable.

Some might see currency volatility as a strong argument for international cooperation. The strongest case for this is that it dampens incentives for private actors to engage in welfare-improving cross-border (or cross-currency) trade, investments, and payments. Certainly there is plenty of evidence that currency stability encourages international economic exchange (for example, López-Córdova and Meissner 2003, and Rose 2000); and this in turn implies that the world would be better off were volatility reduced. There are at least a couple of problems with this. First, while exchange rate volatility may be a serious problem for the international economy, it is not really the result of uninternalized externalities. Volatility is often the result of national policy, to be sure; but its negative effects are almost entirely domestic - national traders, investors, borrowers, and others are deprived of market opportunities. To the extent that the decision to allow a national currency to move around is made by the government, it presumably takes into account the negative impact of this volatility on domestic economic actors. The first second argument against concerted international action to reduce currency volatility is that this volatility may to some extent represent a desirable flexibility in exchange rates. For example, a currency movement to correct an unsustainable misalignment is not a bad thing. The problem typically discussed is "excess volatility," but this is much more likely to be the result of the operation of modern currency markets than the result of government policy. Market actors are probably at the root of much of today's "excess volatility," and it is not clear that cooperative government intervention to restrict foreign exchange markets would be a good thing. So the argument for international cooperation to reduce exchange rate volatility is relatively weak.

Exchange rate misalignments, on the other hand, can be the source of substantial problems for other nations and for international economic relations more generally. A government may purposely keep its currency relative weak, in the expectation that a 
depreciated currency will stimulate exports. ${ }^{4}$ Of course, a depreciated exchange rate has a negative effect on national purchasing power, but this is solely a domestic matter in which the government has decided to trade off the welfare of exporters and importcompetitors, on the one hand, for that of consumers. However, a depreciated currency puts competitive pressure on the country's trading partners, and can stimulate protectionist sentiments abroad. ${ }^{5}$ The result may be to trigger commercial discord between countries, and even to endanger broader trade agreements.

Current conflicts between the United States and China, indeed, illustrate the potential for a currency misalignment to provoke trade tensions. For years, there have been indications that the weak renminbi was inflaming Congressional protectionism, and these sentiments were only moderated when the dollar began to depreciate against other currencies. In an earlier era, the dramatic appreciation of the U. S. dollar in the early 1980s led to major protectionist legislation in the U. S. Congress, and an unprecedented spike in complaints to the International Trade Commission: antidumping cases, for example, rose from an annual average of 24 between 1977 and 1981, to an annual average of 61 between 1982 and 1984 (Deardorff and Stern 1987:26, 23). These exchange rate-provoked conflicts have placed a significant strain on the international trading system, both in bilateral relations between the countries in question, and more generally inasmuch as they have called into question the commitment of major countries to the multilateral resolution of trade disputes. ${ }^{6}$

Another set of examples of how national currency policy can affect other economic ties comes from the interaction of regional currency relations and regional trade agreements. In January 1999, the Brazilian government allowed the real to float, which led to a very substantial depreciation of the currency. This came on the heels of a dramatic expansion of Brazilian-Argentine trade in the context of Mercosur, a trade agreement strongly favored by both governments. But the devaluation, and the overvalued peso associated with Argentina's currency board, provoked a flood of imports into Argentina: in the first eight months of 1999, Argentine imports of Brazilian textiles and footwear rose by 38 and 66 percent respectively. This in turn provoked protests from Argentine manufacturers, who forced the Argentine government to impose barriers on Brazilian iron, textiles, and paper. The Brazilians retaliated, complained to the WTO, and even threatened to dissolve Mercosur (Carranza 2003).

The Mercosur crisis was reminiscent of an earlier episode in the European Monetary System (EMS). The 1992-1993 currency crisis in the EMS led to large devaluations of some EMS currencies. As a result, producers in countries whose currencies had been

\footnotetext{
4 It is of course understood that such policies cannot prevail forever; but there is strong evidence that the rate at which exchange rates converge toward PPP can be quite slow - certainly slow enough to allow such misalignments to have substantial effects on the real economy.

5 Again, this is not a purely economic negative externality: the cheaper products benefit foreign consumers. The point is one of political economy: the increased demand for protection may stimulate retaliatory national policies that harm both countries.

6 There are dissenting views, especially among those who believe that the negative impact of volatility outweighs the positive impact of exchange rate adjustment. See, for example, McKinnon and Schnabl (2006).
} 
stable - in particular France and Germany - came under competitive pressures. This in turn led to domestic complaints about imports from the countries whose currencies had depreciated, which threatened the core commitments of the European Union, especially in the wake of the completion of the single European market. As Barry Eichengreen has noted about the aftermath of the 1992-1993 crisis (Eichengreen 2004):

The choice became whether to turn back to more freely fluctuating exchange rates, which might jeopardize the single market, or to move forward to monetary union, which would eliminate the problem of exchange rate instability by eliminating the exchange rate. Retreating to more flexible exchange rates threatened to fuel a backlash against the single market, since currency depreciation could then confer an arbitrary competitive advantage on some national producers.

In this instance, the alleged undervaluation of some European currencies endangered other economic and non-economic agreements into which EU member states had entered.

Just as relatively depreciated currencies can create negative externalities for governments' trade relations, so can relative appreciated currencies cause problems. This is most clearly the case when a government's attempt to sustain an appreciated exchange rate that is widely regarded as misaligned leads to an attack on the currency that results in a contagious currency crisis. While there are continuing debates over the precise sources and nature of such crises as that in Latin America in 1994-1995 or East Asia in 1997-1998, there is a strong case to be made that in both instances misaligned national currencies created the conditions for speculative attacks both on the initially misaligned currencies and on those of their regional neighbors.

None of this is meant to imply that the actual policies adopted in these instances were inappropriate. Indeed, in most cases they were probably the best the governments in question could do. The United States did not actively attempt to strengthen the dollar after 1981; Brazil should have allowed the real to depreciate in 1999; the EMS members in 1992 should have devalued, and so on. But that is not the relevant question. The relevant question is: could these outcomes have been improved by international cooperation? Could the United States and its principal partners have cooperated more organically before 1985 (when growing concern led to the Plaza Accord)? Could Brazil and Argentina have worked out a collaborative arrangement to allow both their misaligned currencies to depreciate? Could Germany and its EMS partners have developed a cooperative response to German unification? If so, could such cooperation have moderated the currency misalignments, and mitigated their effects on trade and other policies? My answer is a qualified yes. I think that the evidence favors the view that strongly misaligned currencies create problems not just for their home countries but for their economic partners, and in some instances for regional or global economic relations more generally; and that inter-governmental cooperation could in principle help avoid some of the problems that arise as a result.

For while all these cases are different, they have certain features in common. In all instances, policies pursued by national governments concerned about domestic conditions created serious difficulties for other countries. In all instances, the difficulties gave rise to frictions that spilled over into - and typically were most significant for - the non-monetary realm, often trade policy. And this is not surprising. Exchange rate movements are effective substitutes for trade policy - a 10 percent devaluation is equivalent to a 10 percent tariff and a 10 percent export subsidy - but in most cases 
there is no international or bilateral check to such movements while there is to increaseing trade barriers or export subsidies. A government that is constrained by international agreements not to slap on protective tariffs or proffer export subsidies can instead depreciate its currency and achieve much the same effect. Inasmuch as the former policies in the trade realm create negative externalities and thus provide scope for welfare-improving international cooperation, the latter must as well.

The precise nature of the externalities created may vary over time and across place. They would almost certainly include:

1. Artificially weak currencies to gain competitive advantage, which risk imposing costs on trading partners and threatening commercial cooperation.

2. Active policies to depreciate currencies in hard times for "competitive" reasons, which risk provoking a spiral of "competitive devaluations."

3. Artificially strong currencies whose collapse threatens crisis contagion.

The next step is to consider how international cooperation, and perhaps some form of international governance structure, might help alleviate the problems associated with this behavior.

\section{Exchange Rate Cooperation: Motivation and Modalities}

Whatever theory may say about the desirability of international cooperation, and international institutional innovation, they are only feasible if governments are motivated to move in that direction. There is some evidence that the time may be ripe for innovative measures to institutionalize international currency cooperation.

The first indication of at least a latent interest in greater cooperation is that policymakers mention it on a regular basis. While actions speak louder than words, words are not irrelevant, and virtually every major summit meeting on economic issues has expressed a desire for cooperation on currency issues. For example, the April 11, 2008 Statement of G-7 Finance Ministers and Central Bank Governors reads in part: "[T]here have been at times sharp fluctuations in major currencies, and we are concerned about their possible implications for economic and financial stability. We continue to monitor exchange markets closely, and cooperate as appropriate." 7 So there is at least a verbal recognition of the desirability of cooperation.

This recognition includes arguments in favor of more active international monetary cooperation from some of the world's leading academic experts on the subject. William Cline and Morris Goldstein have been explicit about their view that exchange rate cooperation is highly desirable (Cline 2005, Goldstein 2006). Barry Eichengreen has made similar arguments, both in general and with respect to East Asia (Chung and Eichengreen 2007). It is not inconsequential that these highly respected analysts have been outspoken in their views.

There has also, in fact, been some official action in addition to all the many words. A few times in the past 25 years, major governments have felt strongly enough about the global implications of national currency policies to try to work out collaborative

7 Available at http://www.ustreas.gov/press/releases/hp919.htm 
agreements. The best-known are the Plaza and Louvre accords of 1985 and 1987, respectively, meant to address problems associated with the appreciation of the U. S. dollar in the early and middle 1980s, and its aftermath (Funabashi 1988).

More recently, the member states of the International Monetary Fund (IMF) have expanded its mandate quite substantially to include regular surveillance and reporting on exchange rate issues. Of course, the IMF's original activities were heavily oriented toward the exchange rate regime, but with the end of the Bretton Woods system this fell into disuse. In the aftermath of currency crises and substantial misalignments, however, the Fund has been under substantial pressure to reinvigorate this dimension of its activity. The IMF's Independent Evaluation Office produced a series of reports that were highly critical of the Fund's actions in currency crises (Independent Evaluation Office, International Monetary Fund 2003 and 2004), culminating in a critical broad review of the IMF's exchange rate policy advice published in May 2007 (Independent Evaluation Office, International Monetary Fund 2007). In June 2007, the Executive Board adopted a new "Decision on Bilateral Surveillance Over Members' Policies," which was intended to strengthen the role of the IMF in overseeing national currency policies. ${ }^{8}$

Neither of these initiatives, among G-7 members or at the IMF, has been particularly productive, although the IMF endeavor is too new to judge fairly. Nonetheless, their existence is evidence of at least a superficial commitment to do something about the misalignment and volatility of currencies. So there is some evidence of a desire on the part of major governments to work out more fully established mechanisms to cooperate in the determination of national currency policies.

There is, nonetheless, room for skepticism about the international and political feasibility of such plans. Perhaps the most powerful argument that nothing substantial is likely to happen is a simple one: none of the major actors has an incentive to change the current situation. The United States and the euro zone, in particular, can simply impose their exchange rate policy preferences on others. This gives them little reason to want any movement away from the status quo. While there is undoubtedly a lot of truth to this, it is also the case the American and European policymakers do sometimes find themselves facing politically difficult interactions with other governments (as with China); and that American and European policymakers sometimes find themselves at loggerheads with each other. This implies that even for the two great currency powers, there may be room for improvement in the context of a more cooperative international monetary order.

The problem is more general, for it may be that those monetary authorities with the least incentive to act are those whose actions would be most helpful. The governments of the world's principal financial centers (among which I count the European Central Bank) have both the greatest potential to impose costs on others and the greatest ability to ignore those costs. The central position of the major currencies in international trade and payments mean that the policies of the home governments of these currencies have an impact far beyond their borders. At the same time, precisely because the major currencies are issued by governments (or supranational authorities such as the European Central Bank) with responsibility for large and relatively closed economic areas, they may have little incentive to take into account the effects of their actions beyond their

8 The decision is available at http://www.imf.org/external/np/sec/pn/2007/pn0769.htm\#decision 
borders. Policymakers in Washington, Tokyo, or Frankfurt might simply regard the negative externalities they create as less important than the domestic political pressures to which they have to respond. This reality is compounded by the fact that whatever arrangement might be adopted would almost certainly privilege one currency over another, and the major financial powers are unlikely to be of one mind about which currency should be central. ${ }^{9}$

Setting aside these reservations for a moment, what might mechanisms to encourage cooperation in exchange rate policies involve? The first question to answer is what their goals should be. Here it seems clear that the principal purpose envisioned by most, and which the above discussion implies, is to avoid or reverse substantial currency misalignments. Inasmuch as undervalued currencies exacerbate inter-governmental tensions in trade and other policies, and inasmuch as overvalued currencies run the risk of subjecting other countries to contagious crises, international cooperation should aim to reduce the incidence of these misalignments in exchange rates. While the goal of reducing currency volatility may also be relevant, there would seem to be somewhat less scope for that in current circumstances, in which enormous and free-wheeling currency markets are able to affect short-term movements in exchange rates with little difficulty.

How, then, might international initiatives lead governments to alter their policies in a more cooperative direction? Certainly there is little or no scope for coercive measures in this, as in most other international economic relations. International institutions are strictly limited in their ability to enforce compliance with their directives on countries that join voluntarily. They can, however, help national governments converge on punishment strategies for countries that do not conform to accepted principles; and they can also provide information that can affect the behavior of private (and public) actors.

In this context, perhaps the most useful purpose for an international institution charged with monitoring exchange rates would be to make explicit, and public, a determination that a particular national currency was inappropriate, and perhaps unsustainably, misaligned. While some might argue that public identification of the misalignment of a particular currency by an international organization might impose some sort of psychic shaming costs on a government concerned about its reputation, this is unlikely.

A government has pragmatic reasons to be concerned about this sort of misalignment "badge of shame." Such a finding might be seen by currency markets as an indication of the likely future path of the country's exchange rate, prompting market actors to try to anticipate this movement. In this way, an institutional "finding" of overvaluation could prompt a sell-off of the currency and force the currency down. This is somewhat less likely in the case of an undervaluation, for governments find it

9 An even more encompassing observation, in the tradition of modern Political Economy — a tradition to which I generally adhere-might be that it is difficult to imagine the incentives for political supportmaximizing politicans to undertake policies that impose concentrated and visible costs on constituents in order to reap diffuse and hard-to-observe benefits. This may in fact help explain why there has been so little international monetary coordination. Nonetheless, especially in times of crisis, policymakers may find it in their own interest to seek out innovative measures-including those involving international cooperation-in order to reduce the impact of severely negative economic shocks on politically relevant constituencies. Whether current conditions are of this type remains to be seen. 
easier to sterilize a run toward their currency than to defend against a run on it. ${ }^{10}$ Nonetheless, a declaration of misalignment from a respected, circumspect, international organization would be almost certain to provoke a market response, which would tend to push the exchange rate in the "right" direction. Put differently, such a public announcement might serve to help resolve uncertainties about a government's true commitment to an exchange rate target zone, where the target was some generally accepted notion of a realistic real exchange rate. 11

In a sense, this sort of machinery would be analogous to the consensual establishment of target zones for all currencies. The difference is that the target would be one established by some independent authority; and presumably the bands would be quite wide-a currency typically needs to be at least 20 percent above or below some notional equilibrium exchange rate to be considered seriously misaligned. The IMF's Consultative Group on Exchange Rate Issues (CGER) has long worked on a variety of methods to assess exchange rates, with an eye toward identifying deviations from the rate necessary to obtain macroeconomic or external-account balance, or to come close to an equilibrium real exchange rate. ${ }^{12}$ In this context, public and explicit recognition by an authoritative and respected international institution that a currency was misaligned would go a step farther than anything currently existing.

A step even farther past this would be a norm, or a rule, that permitted countries faced with the impact of a recognized misalignment to act to protect themselves. This would be analogous to the right to impose trade sanctions granted by the WTO to winners in WTO disputes. In the case of a depreciated currency, the most likely corrective measure would be temporary trade barriers, although one would hope that the threat of such barriers would make their imposition unnecessary. Indeed, the fact that temporary protection would be permitted in the event of a recognized overvaluation could make the threat more credible. In the case of an appreciated currency, corrective measures might include capital or exchange controls targeted explicitly at the country, or anticipated commitments to coordinated intervention to reduce the threat of contagion if and when the currency were attacked.

I have so far left indeterminate the identity of the international institution that could be charged with this task. The IMF makes the most sense, given its historical commitment to monitoring exchange rate relations and its more recently redoubled effort in this regard. One problem is that the Fund has moved so far in the direction of a development-oriented agency that it might be difficult for Fund findings to have an impact on developed governments. The Bank for International Settlements (BIS) has maintained much of its credibility with advanced industrial countries. Perhaps, as in the sovereign debt realm, some collaborative effort by the IMF and the BIS might be most appropriate.

Whatever institution or mechanism were to embark on this difficult endeavor would need several things to maximize the likelihood of success:

10 This is reminiscent of the adjustment asymmetry between surplus and deficit countries.

11 On the role of expectations about government intentions in the operation of a target zone see, for example, Klein and Lewis (1993).

12 See, for example, Research Department, International Monetary Fund (2006). 
1. A serious commitment from the monetary authorities of the major financial centers.

2. An internationally respected professional staff, at least of the caliber of the IMF and BIS research teams.

3. The political will, on the part of the participating states and the professional staff, to name names as necessary.

4. Consultation with the WTO, both the monitor trade-policy spillovers of currency policies, and to ensure that exchange rate-based trade policy measures are consistent with WTO principles.

Whether any, let alone all, of these things will be forthcoming in the near future is highly debatable. But at least it should be debated. And the current global financial turmoil makes the stakes that much higher. The incentives for countries to act unilaterally rise substantially in times of crisis; and the seriousness of the negative externalities unilateral action can impose also rises substantially. It is easy to imagine circumstances in which uncoordinated macroeconomic policies could seriously deepen the ongoing financial crisis. While the difficulties of coordination may be great, its desirability is almost certainly growing. ${ }^{13}$

Especially in the context of the current crisis, problems and prospects of international monetary cooperation warrant more scholarly and policy attention. It would be particularly useful to have a clearer understanding of the implications of the actions of the principal financial centers, as opposed to small open economies whose global impact is limited. It would also be helpful to explore the conditions under which the major powers could arrive at a collaborative solution to problems of monetary coordination, one that would not impose unacceptably asymmetric costs on participants. We also need a clear picture of the implications of monetary cooperation among the major monetary authorities for countries elsewhere, both in times of crisis and in more normal times. The view that international monetary policy coordination is undesirable or infeasible, or both, has left us with too little understanding of what it might indeed entail. And yet, especially in the light of current problems, all these issues deserve much more focused analytical attention.

\section{Conclusion}

This essay makes the case for systematic inter-governmental cooperation on international monetary affairs. It argues that there are clear and present externalities associated with national exchange rate policies. Whatever one may believe about purely economic externalities in this realm, they are clearly in a broader political-economy sense.

Substantial currency misalignments create especially obvious negative externalities. An artificially depreciated currency creates powerful pressures for trade protection in trading partners, and can threaten the very structure of international commercial relations. An artificially appreciated currency risks "infecting" other countries in the event of a contagious currency crisis. I think that the case for the existence of these

13 For an argument in this direction, see Frieden (2009). 
"spillovers" is clear; that the scope for non-cooperative strategic behavior in the currency realm is also clear; and that the intellectual case for international cooperation is similarly clear. Scholars can help illuminate the options available to national governments, especially in times of crisis. Whether the intellectual clarity of the case is accompanied by incentives for policymakers to act is another matter. 


\section{References}

Busch, Marc L., and Eric Reinhardt (2003). Developing Countries and GATT/WTO Dispute Settlement. Journal of World Trade 37(4): 719-735.

Carranza, Mario (2003). Can Mercosur Survive? Domestic and international constraints on Mercosur. Latin American Politics and Society 45 (2): 67-103.

Chung, Duck-Koo and Barry Eichengreen, editors (2007). Toward an East Asian Exchange Rate Regime. Washington: Brookings Institution.

Cline, William (2005). The Case for a New Plaza Agreement. Policy Brief in International Economics 5-4. Washington: Institute for International Economics.

Corden, Warner Max (1983). The Logic of the International Monetary Non-System. In Fritz Machlup, Gerhard Fels and Hubertus Müller-Groeling (eds.), Reflections on a Troubled World Economy. London: Trade Policy Research Centre.

Davis, Christina (2004). International Institutions and Issue Linkage: Building Support for Agricultural Trade Liberalization. American Political Science Review 98:153-169.

Deardorff, Alan, and Robert Stern (1987). Current Issues in Trade Policy: An Overview. In Robert Stern (ed.), U. S. Trade Policies in a Changing World Economy. Cambridge: MIT Press.

Eichengreen, Barry (2004). What Macroeconomic Measures are Needed for Free Trade to Flourish in the Western Hemisphere? Latin American Politics and Society 46 (2): 1-27.

Frieden, Jeffry (2009). Avoiding the Worst: International Economic Cooperation and Domestic Politics. VoxEU (February 2).

Available online at http://www.voxeu.org/index.php?q=node/2956

Funabashi, Yoichi (1988). Managing the Dollar: From the Plaza to the Louvre. Washington: Institute for International Economics.

Goldstein, Morris (2006). Exchange Rates, Fair Play, and the "Grand Bargain.” Financial Times, April 21.

Hoekman, Bernard M., and Petros C. Mavroidis (2000). WTO Dispute Settlement, Transparency, and Surveillance. World Economy 23(4): 527-542.

Independent Evaluation Office, International Monetary Fund (2003). Evaluation Report: The IMF and Recent Capital Account Crises: Indonesia, Korea, Brazil. Washington: International Monetary Fund.

Independent Evaluation Office, International Monetary Fund (2004). Evaluation Report: The IMF and Argentina, 1991-2001. Washington: International Monetary Fund.

Independent Evaluation Office, International Monetary Fund (2007). IMF Exchange Rate Policy Advice. Washington: International Monetary Fund.

Klein, Michael and Karen Lewis (1993). Learning about Intervention Target Zones. Journal of International Economics 35: 275-295.

López-Córdova, J. Ernesto, and Christopher Meissner (2003). Exchange-Rate Regimes and International Trade: Evidence from the Classical Gold Standard Era. American Economic Review 93, (1): 344-353. 
Mansfield, Edward, Helen V. Milner, and Eric Reinhardt (2002). Why Democracies Cooperate More: Electoral Control and International Trade Agreements. International Organization 56 (3): 477-513.

McKinnon Ronald and Gunther Schnabl (2006). Devaluing the Dollar: A Critical Analysis of William Cline's Case for a New Plaza Agreement. Journal of Policy Modelling 28 (6): 683-694.

Research Department, International Monetary Fund (2006). Methodology for CGER Exchange Rate Assessments. Washington: International Monetary Fund.

Rose, Andrew (2000). One Money, One Market: Estimating the Effect of Common Currencies on Trade. Economic Policy 30: 7-46.

Siebert, Horst (1999). The World Economy. London and New York: Routledge.

Siebert, Horst (2008). The Concept of a World Economic Order. Kiel Working Paper No. 1392 (January). Kiel: Kiel Institute for the World Economy. 


\section{conomics}

The Open-Access, Open-Assessment E-Journal

\section{Please note:}

You are most sincerely encouraged to participate in the open assessment of this article. You can do so by either rating the article on a scale from 1 (bad) to 5 (excellent) or by posting your comments.

Please go to:

www.economics-ejournal.org/economics/journalarticles/2009-6

The Editor 